\title{
Histopathological and immunohistochemical findings of swine with spontaneous influenza A infection in Brazil, 2009-2010
}

\author{
Tatiane T.N. Watanabe ${ }^{2}$, Laura L. de Almeida ${ }^{2}$, Flademir Wouters², Angelica T.B. Wouters ${ }^{2}$, \\ Priscila Zlotowski ${ }^{2}$ and David Driemeier ${ }^{2 *}$
}

\begin{abstract}
Watanabe T.T.N., Almeida L.L., Wouters F., Wouters A.T.B., Zlotowski P. \& Driemeier D. 2012. Histopathological and immunohistochemical findings of swine with spontaneous influenza A infection in Brazil, 2009-2010. Pesquisa Veterinária Brasileira 32(11):1148-1154. Setor de Patologia Veterinária, Faculdade de Veterinária, Universidade Federal do Rio Grande do Sul, Avenida Bento Gonçalves 9090, Porto Alegre, RS 91540-000, Brazil.E-mail: davetpat@ufrgs.br

Swine influenza (SI) is caused by the type A swine influenza virus (SIV). It is a highly contagious disease with a rapid course and recovery. The major clinical signs and symptoms are cough, fever, anorexia and poor performance. The disease has been associated with other co-infections in many countries, but not in Brazil, where, however, the first outbreak has been reported in 2011. The main aim of this study was to characterize the histological features in association with the immunohistochemical (IHC) results for influenza A (IA), porcine circovirus type 2 (PCV2) and porcine reproductive and respiratory syndrome virus (PRRSV) in lung samples from 60 pigs submitted to Setor de Patologia Veterinária at the Universidade Federal do Rio Grande do Sul (SPV-UFRGS), Brazil, during 2009-2010. All of these lung samples had changes characterized by interstitial pneumonia with necrotizing bronchiolitis, never observed previously in the evaluation of swine lungs in our laboratory routine. Pigs in this study had showed clinical signs of a respiratory infection. Swine samples originated from Rio Grande do Sul 31 (52\%), Santa Catarina 14 (23\%), Paraná 11 (18\%), and Mato Grosso do Sul 4 (7\%). Positive anti-IA IHC labelling was observed in $45 \%$ of the cases, which were associated with necrotizing bronchiolitis, atelectasis, purulent bronchopneumonia and hyperemia. Moreover, type II pneumocyte hyperplasia, alveolar and bronchiolar polyp-like structures, bronchus-associated lymphoid tissue (BALT) hyperplasia and pleuritis were the significant features in negative anti-IA IHC, which were also associated with chronic lesions. There were only two cases with positive anti-PCV2 IHC and none to PRRSV. Therefore, SIV was the predominant infectious agent in the lung samples studied. The viral antigen is often absent due to the rapid progress of SI, which may explain the negative IHC results for IA (55\%); therefore, IHC should be performed at the beginning of the disease. This study has shown how important a careful histological evaluation is for the diagnosis. Since 2009, a new histological feature of swine pneumonia in animals with respiratory clinical signs has been observed in samples from pigs with clinical respiratory disease submitted to SPV-UFRGS. In addition, the results proved the importance of histological evaluation for swine herd health management.
\end{abstract}

INDEX TERMS: Swine, influenza A virus, necrotizing bronchiolitis, histopathology, immunohistochemistry.

RESUMO.- [Achados histopatológicos e imuno-histoquímicos de suínos com infecção espontânea de influenza A no Brasil, 2009-2010.] Influenza suína (IS) é uma do-

\footnotetext{
${ }^{1}$ Received on August 9, 2012.

Accepted for publication on September 5, 2012.

${ }^{2}$ Departamento de Patologia Clínica Veterinária, Faculdade de Veterinária, Universidade Federal do Rio Grande do Sul (UFRGS), Av. Bento Gonçalves 9090, Porto Alegre. RS 91540-000, Brazil. *Corresponding author: davetpat@ufrgs.br
}

ença altamente contagiosa, de curso rápido e pronta recuperação, causada pelo vírus influenza tipo A (SIV). Os principais sinais clínicos são tosse, febre, anorexia e baixo desenvolvimento. A doença está presente em outros países e, geralmente, está associada com outros agentes infecciosos. No Brasil, a primeira descrição ocorreu em 2011 e foi associada ao vírus H1N1 pandêmico (pH1N1). O principal objetivo deste estudo foi caracterizar as alterações histológicas em casos de doença respiratória suína sugestiva de 
IS e estudar a associação dessas alterações com os resultados de imuno-histoquímica (IHQ) anti-vírus da influenza A (SIV), anti-circovírus suíno tipo 2 (PCV2) e anti-vírus da síndrome reprodutiva e respiratória (PRRSV). Para tanto, foram estudadas amostras de pulmões de 60 suínos selecionadas dos materiais do arquivo do Setor de Patologia Veterinária da Universidade Federal do Rio Grande do Sul (SPV-UFRGS), de casos de doença respiratória remetidos no período de 2009 a 2010 e que apresentavam alterações histopatológicas compatíveis com pneumonia viral causada pelo SIV. Todas as amostras apresentavam pneumonia intersticial e bronquiolite necrótica muito peculiar que não eram vistas antes na rotina do nosso laboratório. Trinta e uma amostras (52\%) tiveram origem no estado do Rio Grande do Sul, 14 (23\%) do Paraná, 11 (18\%) de Santa Catarina e quatro (7\%) do Mato Grosso do Sul. A IHQ para IA confirmou a presença do agente viral em $45 \%$ das amostras analisadas. Os achados histológicos mais significativos associados à IHQ positiva para IA foram bronquiolite necrótica, atelectasia, broncopneumonia purulenta e hiperemia. Por outro lado, as alterações histológicas dos pulmões estudados, mais significativamente associadas às IHQ negativa para IA foram hiperplasia dos pneumócitos tipo II, estruturas similares a pólipos em alvéolo e bronquíolo, hiperplasia de tecido linfoide associado a brônquios (BALT) e pleurite, que são alterações associadas a processos crônicos. Somente dois casos apresentaram marcação positiva na IHQ para PCV2 e nenhum pulmão foi positivo para PRRSV. Esses resultados sugerem que as lesões histológicas encontradas no presente estudo foram, predominantemente, causadas pelo SIV. Os casos negativos de IHQ para IA (55\%) podem ser explicados pela ausência do antígeno viral nos tecidos estudados. Como o curso da doença é muito rápido, o teste de IHQ é mais indicado para diagnóstico no início da doença. Este estudo possibilitou demonstrar um conjunto de novas alterações histológicas pulmonares de suínos com problemas respiratórios, observadas em amostras pulmonares enviadas ao SPV-UFRGS a partir de 2009. 0 presente trabalho também reforça a importância de estudos histopatológicos dos casos de campo para auxiliar na monitoria da sanidade dos rebanhos suínos.

TERMOS DE INDEXAÇÃO: Suínos, vírus influenza A, bronquiolite necrótica, histopatologia, imuno-histoquímica.

\section{INTRODUCTION}

Swine influenza is a highly contagious and acute respiratory disease of pigs caused by swine influenza type A virus (SIV) (Thomsom \& Easterday 2004, MacLachlan \& Dubovi 2011). The virus has a short incubation period of 1-3 days and a rapid recovery of 5-7 days (Olsen et al. 2006). SI has a low mortality that occurs only in complicated outbreaks. Economic losses are due to severe weight loss or a reduced weight gain in the affected animals of the herd (Olsen et al. 2006, Torremorell 2011, López 2012).

SI has been described in many countries with swine respiratory disease or porcine respiratory disease complex (PRDC) (Van Reeth et al. 2008) Economic losses and the zoonotic potential are important concerns when SIV affects pigs in the herd (Schnitzler \& Schnitzler 2009, Belser et al. 2010, Zanella et al. 2011).

Gathering accurate data from a serological survey demonstrated that different influenza virus strains were circulating around the pig herds of Brazil without any clinical signs (Brentano et al. 2002, Zanella et al. 2011). In 2010, the first outbreak of an acute respiratory disease in pigs associated with SIV was registered, which was isolated from the pandemic H1N1 influenza virus (pH1N1) (Schaefer et al. 2011).

Pulmonary lobular atelectasis with a cranioventral distribution without any secondary infection is the main finding of SI (Thomsom \& Easterday 2004). The most important histologic finding is the epithelial necrosis in the bronchi and bronchioles, which represents cell lysis due to IA infection (Caswell \& Williams 2007).

Immunohistochemistry demonstrates the association between the virus and tissue lesions (López 2012); therefore, it associates cause with effect and has been shown to be a useful tool for detecting IA (Haines et al. 1993, Vincent et al. 1997). The antigen of IA could be demonstrated in formalin-fixed, paraffin-embedded tissue. Furthermore, IHC appears to have nearly equal sensitivity with the virus isolation and is better than immunofluorescence (Vincent et al. 1997).

Moreover, IHC does not require virus manipulation; therefore, the process is safer than viral isolation. In addition, samples fixed in a formalin solution are much easier to work with than fresh or frozen materials (Silveira et al. 2011).

This study aimed to describe the main histological features associated with IHC findings in porcine pneumonia due to SIV and to investigate the occurrence of co-infections between SIV and others viral agents causing pneumonia in Brazilian pigs. In addition, whether there was a co-infection with different viral agents was investigated.

\section{Sample selection}

\section{MATERIALS AND METHODS}

From July 2009 to December 2010, lung samples from 124 pig with a previous histological diagnosis of viral pneumonia, likely previous SIV infection were studied. Samples originated from different farms in different Brazilian States. Sixty samples $(40$ from samples sent to anatomopathological tests and 20 from necropsies) were retrieved from the archives of the Setor de Patologia Veterinária of the Universidade Federal do Rio Grande do Sul (SPV-UFRGS). Data regarding the origin of the herd and the age of the affected animals were collected.

Four porcine categories were used to standardize the affected pigs by age. The pigs were classified into the following categories: farrowing (<21 days old), nursery (21-60 days old), growing-finishing ( $>60$ days old), and information not provided (IN) when there was no data available.

\section{Histopathological studies}

The lung samples were fixed in a 10\% phosphate-buffered formalin solution, embedded in paraffin wax, cut into $3-5-\mu$ m-thick sections, and stained with hematoxylin and eosin (HE) for histological examination.

The sections were systematically examined by evaluating all of the lung tissue structures (bronchi, bronchioli, alveoli and pleura) (Hansen et al. 2010). The inflammatory infiltrate was evalua- 
ted in the alveolar exudates (Bochsler \& Slauson, 2002), within the mucosa of the bronchi and bronchioles, vessels and surrounding tissue. Bronchus-associated lymphoid tissue (BALT) changes were graded according to Ross (1999). Hyperplasia of type II pneumocytes was reported if more than $3 \%$ of the alveolar surface area was lined by these cells (Plopper \& Adams, 2006).

A Masson's trichrome stain was performed to elucidate the connective tissue proliferation (Hansen et al. 2010). The histological features were classified into the following two groups: negative (-) when there was a lack of or a weak intensity, or positive (+) with a moderate or marked intensity.

The BALT evaluation was considered negative for grades $(0),(+)$ and $(++)$; grades $(+++)$ and $(++++)$ were considered positive.

\section{Immunohistochemistry to detect IA, PCV-2, PRRSV and cytoke-} ratin

The sample sections were placed on poly-L-lysine-coated glass slides and heated in a heater at $57^{\circ} \mathrm{C}$ until completely dry for the IHC procedures.

A biotin-streptavidin-peroxidase kit (LSAB kit + System-HRP, Dako®, Carpinteria, CA) was used to demonstrate SIV, PCV2, and PRRSV and identify possible associated viral pathogens. To confirm the presence of type II pneumocyte hyperplasia, IHC for cytokeratin (CK) was applied.

Endogenous peroxidase activity was inhibited by immersing the tissue sections in a $10 \%$ hydrogen peroxide methanol solution for 10 minutes. Antigen retrieval was performed with an enzymatic treatment using $0.05 \%$ protease XIV Sigma $®$ for 25 minutes at $37^{\circ} \mathrm{C}$ for IA, 15 minutes at room temperature for PCV2, proteinase $\mathrm{K}$ ready-to-use (Dako®, Carpinteria, $\mathrm{CA}$ ) for 3 minutes at room temperature for PRRSV and citrate buffer, $\mathrm{pH} 6.0$, at $125^{\circ} \mathrm{C}$, for 3 minutes for $\mathrm{CK}$

The slides were incubated with primary antibodies overnight at $4{ }^{\circ} \mathrm{C}$ with polyclonal antibodies, including anti-IA (Millipore, dilution 1:800) and anti-PCV2 (Sorden et al. 1999, dilution 1:1000). Monoclonal antibodies to anti-PRRSV (Rural Technologies, SDOW17, Nelson et al., 1993, dilution 1:800) and anti-CK (Dako, clone AE1/AE3, dilution 1:80) were made. The chromogen used was 3,3-diaminobenzidine (Dako®, Carpinteria, CA) with Harris' hematoxylin as the counterstain.

Positive immunostaining to SIV was evaluated according to the structure. In this case, the immunostaining was classified into the epithelium of bronchi and/or bronchioles, and/or macrophages. Antigens to PRRSV and PCV2 detected by IHC were negative $(-)$ or positive $(+)$.

\section{Statistical analyses}

To verify the significance between the histological features and IHC results, the data were statistically analyzed using a Chi-squared test or a Fisher's exact test when needed due to a small sample size. In addition, the adjusted residuals were analyzed when necessary. All analyses were performed with SPSS version 18. $P<0.005$ was considered significant.
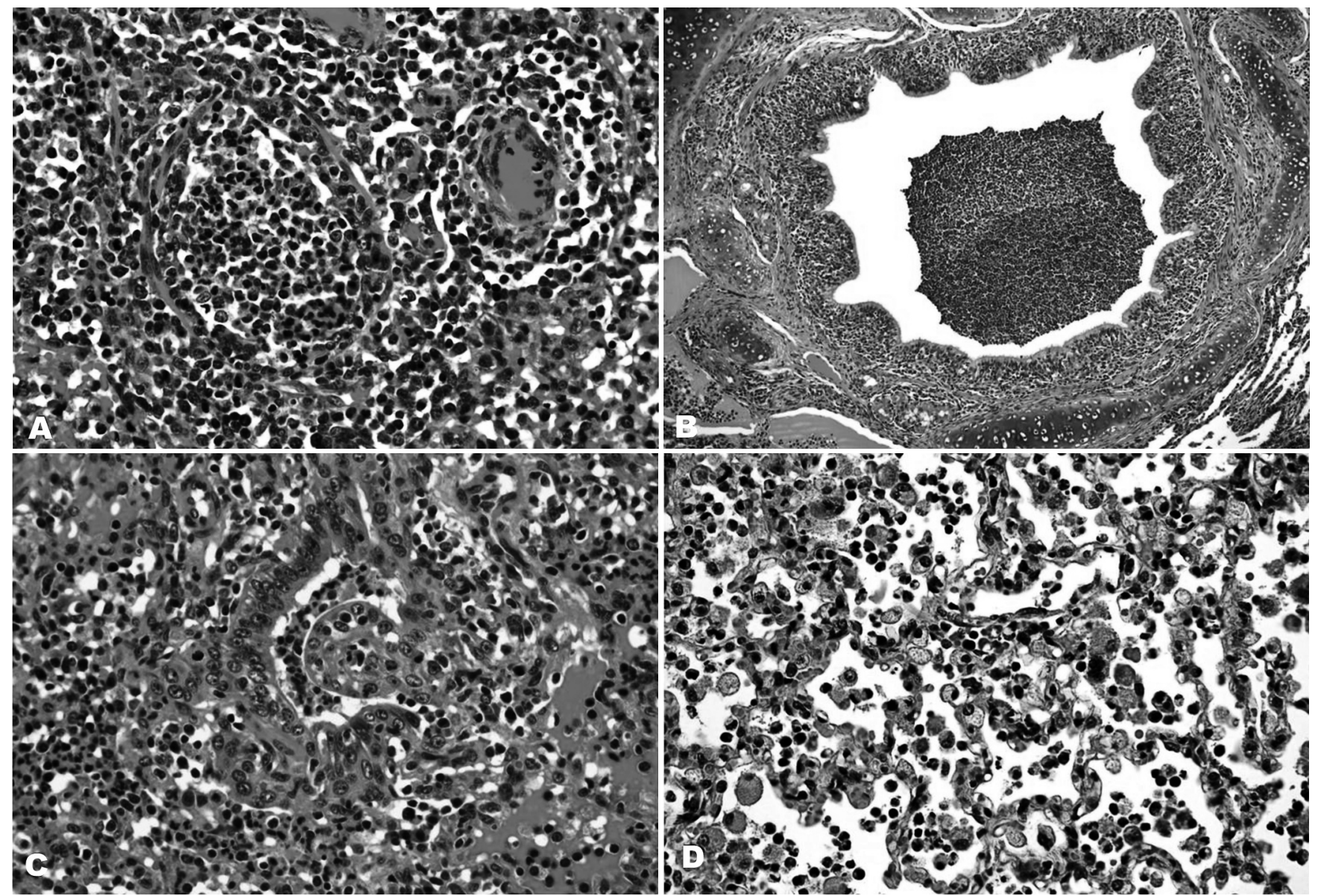

Fig.1. Histopathologic changes of the lung samples due to swine influenza A virus infection. Images of the hematoxylin-and eosin-stained lung sections are shown. (A) Severe necrotizing bronchiolitis. The bronchiolar lumen is occluded by exudate. Intense hyperemia. Obj.40x. (B) Severe suppurative bronchopneumonia, a secondary infection. Obj.10x. (C) Bronchiolar polyp-like structures, covered by type II pneumocytes, bronchiolitis obliterans. Obj 40x. (D) Marked hyperplasia of the type II pneumocytes. Obj.40x. 


\section{RESULTS}

The animal age categories were correlated with the Brazilian States for each herd, according to their geographic origin (Table 1). The evaluated samples included four States. Rio Grande do Sul had the highest prevalence of SIV-affected pig samples in the study. Possibly this predominance

Table 1. The distribution and absolute and relative frequencies of the pig lungs studied at Setor de Patologia Veterinária of Universidade Federal do Rio Grande do Sul during 2009-2010 infected by the swine influenza $A$ virus. The samples are divided into the geographic origin and age category

\begin{tabular}{ccccccc}
\hline \multirow{2}{*}{$\begin{array}{c}\text { Geographic } \\
\text { origin } \\
\text { (State) }\end{array}$} & \multicolumn{3}{c}{ Porcine category/age } & Total & $\begin{array}{c}\text { Affected } \\
\text { animals/ } \\
\text { state (\%) }\end{array}$ \\
\cline { 2 - 5 } Farrowing & $\begin{array}{c}\text { Growing- } \\
\text { Nursery }\end{array}$ & & & & & \\
MS & 0 & 0 & 4 & 0 & 4 & $7 \%$ \\
PR & 2 & 8 & 3 & 1 & 14 & $23 \%$ \\
RS & 2 & 22 & 5 & 2 & 31 & $52 \%$ \\
SC & 2 & 5 & 4 & 0 & 11 & $18 \%$ \\
Total & 6 & 35 & 16 & 3 & 60 & $100 \%$
\end{tabular}

MS = Mato Grosso do Sul State, PR = Paraná State, RS = Rio Grande do Sul State, $\mathrm{SC}=$ Santa Catarina State. ${ }^{*} \mathrm{IN}=$ information not provided.
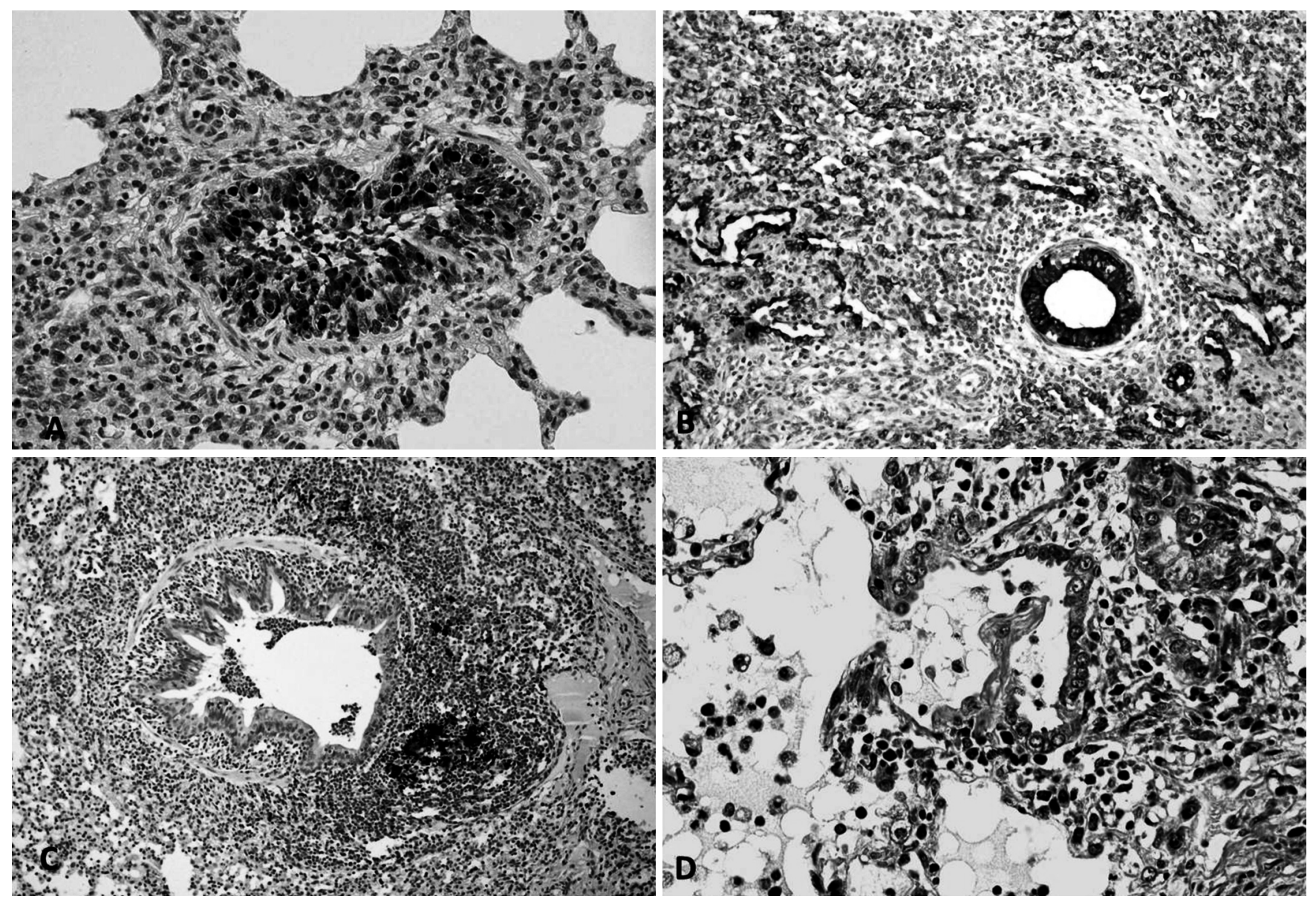

Fig.2. Pig lung tissue section. (A) The immunohistochemical (IHC) streptavidin-biotin-peroxidase complex, with 3,3-diaminobenzidine (DAB) as the chromogen and Harris hematoxylin (counterstain). The goat polyclonal antibody, anti-influenza A. Positive immunostaining of the influenza A virus antigens. There is dark brown staining in many nuclei and the cytoplasm of the bronchiolar epithelial cells. Obj.40x. (B) IHC of the monoclonal mouse anti-cytokeratin, AE1/AE3. There is intense positive cytoplasmic immunostaining to type II pneumocytes, which show hyperplasia. The internal positive control was the bronchiolar epithelium. Obj.20x. (C) IHC of the polyclonal antibody, anti-PCV-2. There is a strong positive cytoplasmic immunoreaction into the macrophages surrounding the bronchiole. Obj.20x. (D) A bronchiolar polyp-like structure with a collagenous core is shown in blue. Masson's trichrome, Obj.40x. 
marked. The positive immunostaining was divided into the following categories: solely bronchioles, bronchi and bronchioles, bronchioles and macrophages, and positive on all structures (bronchi, bronchioles and macrophages). In the bronchioles only, $22 \%(6 / 27)$ of the samples were positive; $18 \%(5 / 27)$ in the bronchi and bronchioles; and 4\% (1/27) in the bronchioles and macrophages. However, in the of majority cases $15 / 27$ (56\%), positive immunostaining was observed in the bronchi, bronchioles and macrophages.

An IHC-positive stain for anti-IA was often observed in the nucleus, and, in some cases, the entire cytoplasm was noted to be diffusely brown (Fig.2a). The difference between the positive cells of the bronchi and bronchioles was well marked. A large number of positive-stained cells were observed in the bronchiolar epithelium, as compared to the bronchial epithelium. Within the age categories, $67 \%$ of the farrowing pigs had a positive IHC to IA in at least the bronchioles. Animals from the completed growth and nursery groups had a similar frequency of positive IHC, $44 \%$ and $43 \%$, respectively (Table 2).

One out of six piglets from the farrowing group was only three days of age. The others were an average of 13 days old.

The histological findings are summarized in Tables 3 and 4. The most frequent histologic lesions observed in association with positive IHC for IA were necrotizing bronchiolitis 93\% (25/27) (Fig.1a), atelectasia 85.2\% (23/27) and purulent bronchopneumonia 66.7\% (18/27) (Fig.1b). However, the least frequently associated histologic lesions were pleuritis $11.1 \%$ (3/27), BALT hyperplasia 7.4\% (2/27) and

Table 3. Frequencies of the main histological lesions observed and associated with a positive IHC to the influenza $A$ virus in 27 swine lungs studied during 2009-2010 at Setor de Patologia Veterinária of Universidade Federal do Rio Grande do Sul

\begin{tabular}{|c|c|c|}
\hline Histological findings* & $\begin{array}{c}\text { Positive IHC to } \\
\text { Influenza A virus (\%) }\end{array}$ & $P$ value** \\
\hline Necrotizing bronchiolitis & $93(25 / 27)$ & 0.002 \\
\hline Atelectasis & $85.2(23 / 27)$ & 0.003 \\
\hline Purulent bronchopneumonia & $66.7(18 / 27)$ & 0.005 \\
\hline Interstitial pneumonia & $66.7(18 / 27)$ & NS \\
\hline Emphysema & $33(9 / 27)$ & NS \\
\hline Alveolar mixed inflammatory infiltrate & $59.3(16 / 27)$ & NS \\
\hline Hyperemia & $51.9(14 / 27)$ & 0.006 \\
\hline Bronchiolar ectasia & $51.9(14 / 27)$ & NS \\
\hline Vasculitis & $48.1(13 / 27)$ & NS \\
\hline Attenuation of bronchiolar epithelial cells & $48.1(13 / 27)$ & NS \\
\hline Type II pneumocyte hyperplasia & $37(10 / 27)$ & 0.04 \\
\hline Alveolar edema & $33.3(9 / 27)$ & NS \\
\hline $\begin{array}{l}\text { Mixed inflammatory infiltrate of bron- } \\
\text { chiolar mucosa }\end{array}$ & $18.5(5 / 27)$ & NS \\
\hline $\begin{array}{l}\text { Bronchus and/or bronchiole epithelium } \\
\text { hyperplasia }\end{array}$ & $14.8(4 / 27)$ & NS \\
\hline $\begin{array}{l}\text { Mononuclear inflammatory infiltrate of } \\
\text { bronchiolar mucosa }\end{array}$ & $14.8(4 / 27)$ & NS \\
\hline Pleuritis & $11.1(3 / 27)$ & 0.04 \\
\hline BALT hyperplasia & $7.4(2 / 27)$ & 0.002 \\
\hline $\begin{array}{l}\text { Alveolar or bronchiole polyp-like } \\
\text { structures }\end{array}$ & $0(0 / 27)$ & $<0.001$ \\
\hline \multicolumn{3}{|c|}{$\begin{array}{l}\text { IHC }=\text { immunohistochemistry, }{ }^{*} \text { Considered when the score was moderate } \\
(++) \text { or marked }(+++),{ }^{* *} P \text { values were calculated by either the Chi-squa- } \\
\text { red or Fisher's exact test, as appropriate, for the association between } \\
\text { the histological findings and positive IHC for influenza } A ; P \text { value }<0.05 \text {. } \\
\text { NS = not significant; } P \text { value greater than } 0.05 \text {. }\end{array}$} \\
\hline
\end{tabular}

Table 4. Frequencies of the main histological features observed in 33 swine lungs that were associated with a negative IHC to the influenza A virus analyzed during 2009-2010 at Setor de Patologia Veterinária, Universidade Federal do Rio Grande do Sul

\begin{tabular}{lcc}
\hline \multicolumn{1}{c}{ Histological findings* } & $\begin{array}{c}\text { Negative IHC to the } \\
\text { influenza A virus (\%) }\end{array}$ & $P$ value** \\
\hline Interstitial pneumonia & $72.7(24 / 33)$ & NS \\
Emphysema & $69.7(23 / 33)$ & NS \\
Type II pneumocyte hyperplasia & $63.6(21 / 33)$ & 0.040 \\
Alveolar mixed inflammatory infiltrate & $60.6(20 / 33)$ & NS \\
Necrotizing bronchiolitis & $57.6(19 / 33)$ & 0.002 \\
Vasculitis & $54.5(18 / 33)$ & NS \\
Bronchiolar ectasia & $54.5(18 / 33)$ & NS \\
Alveolar or bronchiole polyp-like struc- & $51.5(17 / 33)$ & $<0.001$ \\
tures & & \\
Atelectasis & $48.9(16 / 33)$ & 0.003 \\
BALT hyperplasia & $42.4(14 / 33)$ & 0.002 \\
Bronchus and/or bronchiole epithelium & $36.4(12 / 33)$ & NS \\
$\quad$ hyperplasia & & \\
Mononuclear inflammatory infiltrate of & $36.4(12 / 33)$ & NS \\
$\quad$ bronchiolar mucosa & $33.3(11 / 33)$ & 0.040 \\
Pleuritis & $33.3(11 / 33)$ & NS \\
Attenuation of bronchiolar epithelial cells & $30.3(19 / 33)$ & 0.005 \\
Purulent bronchopneumonia & $27.3(9 / 33)$ & NS \\
Alveolar edema & $18.2(6 / 33)$ & 0.006 \\
Hyperemia & $0(0 / 33)$ & NS \\
Alveolar neutrophilic inflammatory infil- & &
\end{tabular}

IHC = immunohistochemistry, ${ }^{*}$ Considered when the score was moderate $(++)$ or marked $(+++) .{ }^{* *} P$ values were calculated by either the Chi-squared or Fisher's exact test, as appropriate, for the association between the histological findings and negative IHC for influenza A; $P$ value $<0.05$. NS $=$ not significant; $P$ value greater than 0.05 .

alveolar or bronchiolar polyp-like structures $0 \%(0 / 27)$, all of which had a $P$ value $<0.05$. In addition, hyperemia $51.9 \%$ $(14 / 27)$ and type II pneumocyte hyperplasia $37 \%(10 / 27)$ were also statistically significant (Table 3 ).

The most frequent histological findings of the IHC negative cases were interstitial pneumonia $72.7 \%(24 / 33)$ and emphysema $69.7 \%$ (23/33), followed by type II pneumocyte hyperplasia 63.6\% (21/33) (Figs. 1d and 2b). Alveolar edema $27.3 \%$ (9/33), hyperemia $18.2 \%(6 / 33)$ and alveolar neutrophilic inflammatory infiltrate $0 \%(0 / 33)$ were less frequently observed.

Although histologic features, such as necrotizing bronchiolitis $57.6 \%$ (19/33), alveolar or bronchiolar polyp-like structures $51.5 \%$ (17/33) (Figs.1c and 2d), atelectasis 48.9\% (16/33), BALT hyperplasia (14/33), pleuritis $(11 / 33)$ and purulent bronchopneumonia (19/33), had an average frequency, all of which were of significance under statistic tests (Table 4). As shown by statistical analysis, the positive anti-IA by IHC result has a positive association with necrotizing bronchiolitis, atelectasis, purulent bronchopneumonia and hyperemia. However, pleuritis, BALT hyperplasia, alveolar or bronchiolar polyp-like structures, and type II pneumocyte hyperplasia have a positive association with negative IHC results for IA, according to the adjusted values.

The IHC results for the other agents showed no positive results for PRRSV; however, only two cases 3\% (2/60) had positive immunostaining to PCV2 in the lung macrophages (Fig. 2c), but no immunoreaction to IA was detected. 


\section{DISCUSSION}

During 2009-2010, SI was diagnosed in 124 lungs at SPV-UFRGS based on a histological evaluation, and 60 of these were reported in this study. SI is not restricted to only one Brazilian state. These samples originated from four different Brazilian States. It seems that large commercial swine herds have been affected.

Furthermore, in almost the same period (2009), the first case of infection by the pH1N1 virus was reported in pigs (Evans 2009). In Brazil, the infection occurred almost one year later, after the virus isolation and the disease characterization in symptomatic pigs (Schaefer et al. 2011). Since this time, a histological pattern (according to the SPV-UFRGS database) of necrotizing bronchiolitis has been observed more frequently in swine lungs.

These lesions were caused by a new virus, and the absence of immunity could explain why an acute disease was observed in each herd (Flores et al. 2007, Linhares \& Vannucci 2011, Torremorell 2011). SI affected animals in all age categories, from farrowing until the end of the production cycle.

SIV transmission occurs directly from pig-to-pig by infectious droplets, aerosolization, or contact with infected secretions (Caswell \& Williams 2007, López 2012). The three-day-old piglet in the farrowing group may be infected soon after birth. Studies show that the incubation period is 2-3 days (MacLachlan \& Dubovi 2011), 1-4 days (Sreta et al. 2009), or even 1-3 days (Canal 2006, Olsen et al. 2006). These data show that even after a few moments of birth, piglets could be infected.

Although the severity of SI may be enhanced by viral co-infections (Yazawa et al. 2004, Olsen et al. 2006, Grau-Roma \& Segalés 2007), very few cases had a positive immunoreaction to PCV-2. Preventative methods used in most commercial Brazilian herds, such as vaccinations used in other countries (Grau-Roma et al. 2011), may explain why there was a low frequency of this finding. None of the studied samples were PRRSV positive, which further proves that there are no episodes of this disease in Brazil (Ciacci-Zanella et al. 2002, Ciacci-Zanella et al. 2004, Ciacci-Zanella 2006).

Aujeszky's disease was not investigated in this study. Serological research of swine herds has produced negative results (Souza et al. 2002, Groff et al. 2005, Schaefer et al. 2006, Ciacci-Zanella et al. 2008). Moreover, there were no reports of neurologic or reproductive clinical signs in these studied cases.

Although some samples had BALT hyperplasia and purulent bronchopneumonia that could be associated with Mycoplasma hyopneumoniae, necrotizing bronquiolitis were the most frequent features observed, which is not typical of swine enzootic pneumonia.

Other factors, such as stress, climate changes, or another concurrent disease, could complicate the SI clinical signs (Flores et al. 2007, Zanella 2007, Vincent et al. 2008); however, these factors were not studied in this report (with the exception of PCV2 and PRRSV).

Moreover, a great number of cases had purulent bronchopneumonia, meaning that secondary bacterial infections increased the lung lesions.
An endemic form of SI is increasingly common in other countries. Furthermore, bacterial secondary bronchopneumonia has been described frequently with a range in severity (Caswell \& Williams 2007). This complication is more important in the beginning of the disease course, as the frequency decreases by half when the IHC is negative for IA.

In many studied cases, positive immunostaining for IA was not demonstrated; nevertheless, there were histological features of SIV infection. These cases could also be associated with the absence of the viral antigen, sometimes, as early as 72 hours after the infection (Caswell \& Williams 2007). In addition, prolonged formalin fixation could decrease antigen marker by IHC (Webster et al 2009 and 2010).

According to this study, the severity of the histological lesions might be explained by the lack an immune response to a new virus type, as observed in other countries (Schnitzler \& Schnitzler 2009, Marks \& Canal 2010, Brookes \& Brown 2011, Kim et al. 2011,). Collectively, these results suggest that SIV antigens detected by IHC could be better detected in the acute phase of the disease; specifically, there are more antigens during the first few hours or days of infection. Necrotizing bronchiolitis, atelectasis, purulent bronchopneumonia and hyperemia are histologically associated, whereas the chronic form of the disease has a negative IHC for the viral antigen. Furthermore, type II pneumocyte hyperplasia, alveolar or bronchiolar polyp-like structures, BALT hyperplasia and pleuritis are the main histological lesions observed, all of which suggest a chronic lesion (López 2012).

All of the historical features that were identified in this study are indicative of SI, and IHC confirms the real presence of IA (Olsen et al. 2006, Caswell \& Williams 2007, López 2012); however, for achieving better results, the lung tissue must be collected at the first appearance of clinical signs and must be well fixed with $10 \%$ buffered formalin to avoid any kind of artifact (Haines et al. 1993). Samples that are collected after this period may have a false negative result, which makes the diagnosis of the herd a challenge.

As this study has shown, a new histological feature of swine pneumonia from animals with respiratory clinical signs has been observed in the samples submitted to SPV-UFRGS since 2009.

Acknowledgements.- The authors wish to thank Prof. Elsa Mundstock and her team for the statistical analysis from "Núcleo de Assessoria Estatística" of Universidade Federal do Rio Grande do Sul. This study was supported by Grants from the Conselho Nacional de Desenvolvimento Científico e Tecnológico (CNPq) and the Coordenação de Aperfeiçoamento de Pessoal de Nível Superior (CAPES), Brazil.

\section{REFERENCES}

Belser J.A., Wadford D.A., Pappas C., Gustin K.M., Maines T.R., Pearce M.B., Zeng H., Swayne D.E., Pantin-Jackwood M., Katz J.M. \& Tumpey T.M. 2010. Pathogenesis of pandemic influenza A (H1N1) and triple-reassortant swine influenza A (H1) viruses in mice. J. Virol. 84(9):41944203.

Bochsler P.N. \& Slauson D.O. 2002. Inflammation and repair tissue, p.140245. In: Slauson D.O. \& Cooper B.J. (Eds.), Mechanisms of Disease: A textbook of comparative general pathology. $3^{\text {rd }}$ ed. Mosby Inc., St Louis.

Brentano L., Zanella J.R.C., Mores N. \& Piffer I. A. 2002. Levantamento soro- 
epidemiológico para coronavírus respiratório e da gastroenterite transmissível e dos vírus da influenza H3N2 e H1N1 em rebanhos suínos no Brasil. Comum. Téc. 306, Embrapa Suínos e Aves, Concórdia, SC, p.1-6.

Brookes S.M. \& Brown I.H. 2011. A/H1N1/pdm09 virus: dynamics of infection in pigs and people. Vet. Rec. 169:151-152.

Caswell J.L. \& Williams K.J. 2007. Respiratory system, p.579-587. In: Maxie M.G. (Ed.), Jubb, Kennedy and Palmer's Pathology of Domestic Animals. Vol.2. $5^{\text {th }}$ ed. Saunders Elsevier, Philadelphia.

Ciacci-Zanella J.R., Brentano L., Bassi S., Flores S., Schiochet M., Mocelim A.C., Costa D.E.M., Vargas I. \& Nemoto S.M.L. 2002. Estudo de prevalência de anticorpos para o vírus da síndrome reprodutiva e respiratória dos suínos (PRRS) em granjas de suínos no Brasil. Comum. Téc. 295, Embrapa Suínos e Aves, Concórdia, SC.

Ciacci-Zanella J.R., Trombetta C., Vargas I. \& Costa D.E.M. 2004. Lack of evidence of porcine reproductive and respiratory syndrome virus (PRRSV) infection in domestic swine in Brazil. Ciência Rural 34(2):449-455.

Ciacci-Zanella J.R. 2006. PRRSV-Síndrome reprodutiva e respiratória dos suínos "Situação da infecção no Brasil e como evitar a doença nos nossos rebanhos". Anais I Simpósio UFRGS sobre Produção, Reprodução e Sanidade Suína, Porto Alegre, RS.

Ciacci-Zanella J.R., Amaral A.L., Ventura L.V., Morés N. \& Bortoluzzi H., 2008. Erradicação da doença de Aujeszky em Santa Catarina: importância da condição sanitária das leitoas de reposição. Ciência Rural 38(3):749-754.

Evans B. 2.5.2009: A/H1N1 influenza, Canada (immediate notification). IE/World Animal Health Information Database Weekly Disease Information 2009; 22(19); Available at <http://www.oie.int/wahis/public. php?page=weekly_report_index $>$ Accessed Sept. 3, 2010.

Flores E.F., Lovato L.T., Silva M.S., Dezengrini R. \& Diel D.G. 2007. Orthomyxoviridae, p.723-754. In: Flores E.F. (Ed.), Virologia Veterinária. Editora da UFSM, Santa Maria.

Grau-Roma L. \& Segalés J. 2007. Detection of porcine reproductive and respiratory syndrome virus, porcine circovirus type 2 , swine influenza virus and Aujeszky's disease virus in cases of porcine proliferative and necrotizing pneumonia (PNP) in Spain. Vet. Microbiol. 119:144-151.

Grau-Roma L., Fraile L. \& Segalés J. 2011. Recent advances in the epidemiology, diagnosis and control of diseases caused by porcine circovirus type 2. Vet. Journal 187:23-32.

Groff F.H., Merlo M.A., Stoll P.A., Stepan A.L., Weiblen R. \& Flores E.F. 2005. Epidemiologia e controle dos focos da doença de Aujeszky no Rio Grande do Sul, em 2003. Pesq. Vet. Bras. 25(1):25-30.

Haines D.M., Waters E.H. \& Clark E.G. 1993. Immunohistochemical detection of swine influenza A virus in formalin-fixed and paraffin-embedded tissues. Can. J. Vet. Res. 57:33-36.

Hansen M.S., Pors S.E., Jensen H.E., Bille-Hansen V., Bisgaard M., Flachs E.M. \& Nielsen O.L. 2010. An investigation of the pathology and pathogens associated with porcine respiratory disease complex in Denmark. J. Comp. Pathol. 143:120-131.

Kim S.-H., Moon O.-K., Lee K.-K., Song Y.-K., Yeo C.-L., Bae C-W., Yoon H., Lee O.-S., Lee J.-H. \& Park C.-K. 2011. Outbreak of pandemic influenza (H1N1) 2009 in pigs in Korea. Vet. Rec. 169:155.

Linhares D. \& Vannucci F. 2011. Atualização e futuras perspectivas no diagnóstico e controle da influenza suína no Brasil. Suínos e Cia 39:24-28.

López A. 2012. Respiratory system, p.458-538. In: McGavin M.D. \& Zachary J.F. (Eds), Pathologic Basis of Veterinary Disease. $5^{\text {th }}$ ed. Mosby Elsevier, St Louis.

MacLachlan N.J. \& Dubovi E.J. 2011. Orthomyxoviridae, p.353-370. In: Ibid. (Eds), Fenner's Veterinary Virology. $4^{\text {th }}$ ed. Elsevier Inc., Amsterdam.

Marks F.S. \& Canal C.W. 2010. Etiologia e diagnóstico da infecção causada pelo vírus da influenza (novo vírus e vírus da gripe estacional humana) em suínos. Acta Scient. Vet. 38 (Supl.1):37-43.

Olsen C.W., Brown I.H., Easterday B.C. \& Van Reeth K. 2006. Swine influen- za, p.469-482. In: Straw B.E., Zimmerman J.J., D’Allaire S. \& Taylor D.J. (Eds), Diseases of Swine. $9^{\text {th }}$ ed. Blackwell Publishing, Iowa.

Plopper C.G. \& Adams D.R. 2006. Respiratory system, p.153-169. In: Eurell J.A. \& Frappier B.L. (Eds), Dellmann's Texbook of Veterinary Histology. $6^{\text {th }}$ ed. Blackwell Publishing, Iowa.

Van Reeth K., Brown I.H., Dürrwald R., Foni E., Labarque G., Lenihan P., Maldonado J., Markowska-Daniel I., Pensaert M., Pospisil Z. \& Koch G. 2008. Seroprevalence of H1N1, H3N2 and H1N2 influenza viruses in pigs in seven European countries in 2002-2003. Influenza Other Resp. Viruses 2(3):99-105.

Ross R.F. 1999. Mycoplasmal disease, p.495-509. In: Straw B.E., D’Allaire S., Mengeling W.L. \& Taylor D.J. (Eds), Diseases of Swine. $8^{\text {th }}$ ed. Blackwell Publishing, Iowa.

Schaefer R., Ciacci-Zanella J., Mores N., Pan K.A., Dambros R.M.F., Schiochet M.F. \& Coldebella M. 2006. Caracterization of Aujeszky's disease virus isolated from South Brazil in the last twenty years by restriction enzyme analysis. Braz. J. Microbiol. 37:390-394.

Schaefer R., Zanella J.R.C., Brentano L., Vincent A.L., Ritterbusch G.A., Silveira S., Caron L. \& Mores N. 2011. Isolation and characterization of a pandemic H1N1 influenza virus in pigs in Brazil. Pesq.Vet. Bras. 31(9):761-767.

Schnitzler S.U. \& Schnitzler P. 2009. An update on swine-origin influenza virus A/H1N1: A review. Virus Genes 39:279-292.

Silveira S., Schiochet M.F., Simon N., Gava D., Rocha C.S., Schaefer R. \& Ciacci-Zanella J.R. 2011. Isolamento do vírus influenza A em suínos. Anais I Mostra de Iniciação Científica, Concórdia, SC.

Souza C.M., Sobestiansky J., Matos M.P.C. \& Caiado K.L. 2002. Prevalência da infecção pelo vírus da doença de Aujeszky em matrizes de sistemas de produção que abastecem o mercado consumidor da Gôiania. Ciênc. Anim. Bras. 3(2):53-56.

Sreta D., Kedkovid R., Tuamsang S., Kitikoon P. \& Thanawongnuwech R. 2009. Pathogenesis of swine influenza virus (Thai isolates) in weanling pigs: An experimental trial. Virol. J. 6:34-44.

Thomsom G.R. \& Easterday B.C. 2004. Swine influenza, p.775-783. In: Coetzer J.A.W. \& Tustin R.C. (Eds), Infectious Diseases of Livestock. Vol.2. $2^{\text {nd }}$ ed. Oxford University Press, Cape Town.

Torremorell M. 2011. New developments on the infection with influenza virus in pigs. Anais VI Simpósio internacional de suinocultura (Sinsui), Porto Alegre, RS, p.95-100.

Vincent L.L., Janke B.H., Saul P.S. \& Halbur P.G. 1997. A monoclonal-antibody-based immunohistochemical method for the detection of swine influenza virus in formalin-fixed, paraffin-embedded tissues. J. Vet. Diagn. Invest. 9:191-195.

Vincent A.L., Ma W., Larger K.M., Janke B.H. \& Richt J.A. 2008. Swine influenza viruses a North American perspective. Adv. Virus Res. 72:127157.

Yazawa S., Okada M., Ono M., Fujii S., Okuda Y., Shibata I. \& Kida H. 2004. Experimental dual infection of pigs with an H1N1 swine influenza virus (A/Sw/Hok/2/81) and Mycoplasma hyopneumoniae. Vet. Microbiol. 98:221-228

Webster J.D., Miller M.A., DuSold D. \& Ramos-Vara J. 2009. Effects of prolonged fixation on diagnostic immunohistochemistry in domestic animals. J. Histochem. Cytochem. 57(8):753-761.

Webster J.D., Miller M.A., DuSold D. \& Ramos-Vara J. 2010. Effects of prolonged formalin fixation on the immunohistochemical detection of infectious agents in formalin-fixed, paraffin-embedded tissues. Vet. Pathol. 74(3):529-535.

Zanella C.J. 2007. Gripe suína, p.268-270. In: Sobestiansky J. \& Barcellos D. (Eds), Doenças dos Suínos. Cânone Editorial, Gôiania.

Zanella J.R.C., Vincent A.L., Schaefer R. \& Caron L. 2011. Influenza em suínos no Brasil: o problema e o que pode ser feito para manter a infecção controlada nas granjas afetadas. Anais VI Simpósio internacional de Suinocultura (Sinsui), Porto Alegre, RS, p.85-92. 